\title{
Peningkatan Perilaku Prososial Mahasiswa PGSD Melalui Strategi Ecopedagogy Berbasis Learning Community
}

\author{
Noer Intan Novitasari, Zafar Sodik Alatas \\ STKIP Majenang \\ noerinta1290@gmail.com
}

\section{Sejarah Artikel}

diterima 18 September 2020 disetujui 20 November 2020 diterbitkan 1 Desember 2020

\begin{abstract}
Based on preliminary study in preservice primary school teachers' prosocial behavior tends to be at a normative level of $54 \%$. This study aims to improve the prosocial behavior of STKIP Majenang students through the application of ecopedagogy learning community-based. This type of research used a Classroom Action Research design through four typical KemmisTaggart stages. The particapant of this research was 20 first year students in 2019/2020 of primary school teacher education program in Majenang Teacher Training and Education Institute. The data collection technique consists of three instruments interviews, observations, and questionnaires to determine the implementation of learning and student prosocial behavior. The results showed an increase in two aspects: 1) the implementation of learning communitybased ecopedagogy in cycle 1 was 51\% and cycle 2 was 79\%; 2) students' prosocial behavior in cycle 1 was $61 \%$ and cycle 2 was $76 \%$.
\end{abstract}

Keywords: Prosocial behavior, ecopedadogy, PGSD Student

\begin{abstract}
Abstrak
Berdasarkan studi pendahuluan yang dilakukan kepada mahasiswa STKIP Majenang menunjukkan bahwa perilaku prososial mahasiswa cenderung berada pada tingkatan normatif sebesar $54 \%$. Penelitian ini bertujuan untuk meningkatkan perilaku prososial mahasiswa STKIP Majenang melalui penerapan pembelajaran ecopedagogy berbasis learning community. Jenis penelitian menggunakan desain Penelitian Tindakan Kelas melalui empat tahapan khas Kemmis-Taggart. Subyek penelitian ini merupakan mahasiswa PGSD tahun angkatan 2019 sebanyak 20 orang. Teknik pengumpulan data terdiri dari tiga instrument yakni wawancara, observasi, dan angket untuk mengetahui keterlaksanaan pembelajaran dan perilaku prososial mahasiswa. Hasil penelitian menunjukkan adanya peningkatan dua aspek yang diteliti, antara lain: 1) keterlaksanaan pembelajaran ecopedagogy berbasis learning community pada siklus 1 sebesar $51 \%$ dan siklus 2 sebesar $79 \%$; 2) perilaku prososial mahasiswa pada siklus 1 sebesar $61 \%$ dan siklus 2 sebesar $76 \%$.
\end{abstract}

Kata kunci: Perilaku prososial, ecopedadogy, mahasiswa PGSD 


\section{PENDAHULUAN}

Intensitas penggunaan teknologi dalam kehidupan manusia sehari-hari tidak hanya memberikan pengaruh positif terhadap inovasi, kreatifitas, dan daya saing global. Sayangnya, momentum pemanfaatan teknologi sebagai pengembangan kapasitas intelektual sejalan dengan tergerusnya perilaku prososial dimasyarakat. Perilaku prososial merupakan sebuah kesadaran yang dilakukan untuk memberikan bantuan kepada orang lain (Lampridis \& Papastylianou, 2014). Definisi ini memiliki implikasi bahwa tindakan membantu satu orang dapat bermanfaat bagi keduanya, penolong dan penerima.

Hasil studi pendahuluan melalui angket kepada 20 responden menunjukkan bahwa rata-rata perilaku prososial mahasiswa berada di tingkatan normatif sebesar $54 \%$. Hasil ini mencakup empat sub aspek dari perilaku prososial, yaitu patuh, altruistik, emosional, dan publik. Secara umum, hampir seluruh mahasiswa bersedia dan pernah memberikan bantuan ketika diminta pertolongan baik secara verbal maupun non verbal (patuh). Namun, hal ini sangat kontras jika dibandingkan dengan kesediaan pemberian bantuan secara sukarela (altruistik) maupun emosional.

Fakta ini kemudian didukung dengan hasil wawancara kepada 6 informan terpilih yang menghasilkan beberapa poin inti, antara lain: (a) aktivitas berbagi didominasi oleh mahasiswa dengan tingkat akademis sedang, misalnya kesediaan menempatkan pengetahuan dan kemampuan kepada teman yang notabene tidak memiliki kedekatan interpersonal; (b) aktivitas membantu sebagian besar dilakukan secara spontan dan sukarela kepada teman yang dirasakan memiliki kedekatan secara emosional. Sementara bantuan dipengaruhi pula oleh pertimbangan gender. Adapun bantuan diberikan kepada teman atas dorongan pengakuan diri (publik); dan (c) mahasiswa mampu merasakan apa yang dirasakan teman, namun kesulitan untuk menempatkan diri pada posisi teman yang merasa tidak nyaman.

Berdasarkan temuan tersebut, masalah kecenderungan perilaku prososial mahasiswa didasari oleh motif yang melekat pada pribadi. Dalam hal ini terdapat dua jenis bentuk tindakan, yaitu pemberian bantuan timbul dari inisiatif atau yang dikatakan sebagai motivasi otonom. Sebaliknya, perilaku yang berasal dari tekanan eksternal atau penghargaan dikatakan sebagai motivasi yang terkontrol (Vecina \& Chacon, 2013). Namun demikian, dalam sebuah studi di perguruan tinggi menemukan bahwa mahasiswa dengan tingkat akademik tinggi dapat merespon dengan baik motivasi eksternal yang memberi status dan meningkatkan perasaan harga diri mereka (Geiser, Okun, \& Grano, 2014). Hal ini menunjukkan bahwa pengakuan publik atas upaya mereka dan umpan balik positif tentang kinerja tugas dapat meningkatkan perilaku prososial.

Mengacu pada fenomena yang terjadi pada mahasiswa STKIP Majenang, maka diperlukan adanya suatu pendekatan pendidikan yang mampu mengintegrasikan perilakuperilaku prososial mahasiswa secara 
lebih otonom dan holistik. Sejalan dengan pembangunan berkelanjutan (Sustainable development), pendidikan menjadi jembatan di antara tujuan lingkungan, ekonomi, dan sosial. Ecopedagogy adalah sebuah gerakan yang berkaitan dengan dimensi kosmologis, teknologi, dan organisasi dari kehidupan sosial. Pembelajaran Ecopedagogy diasumsikan sebagai pendekatan tindakan transformative pedagogis atau pengajaran dalam konteks pendidikan lingkungan (Apple \& Au, 2009).

\section{Bagian}

ecopedagogy mempertimbangkan dan mengkritik manfaat dari tindakan yang membahayakan

Sebagaimana mengemukakan

Misiaszek lingkungan.

fundamental ecopedagogy adalah memiliki pemahaman yang lebih mendalam dan kontekstual tentang hasil positif dan negatif melalui pengajuan sebuah masalah.

Senada dengan hal tersebut, cara paling efektif dalam skema pembelajaran ecopedagogy adalah dengan melibatkan individu dalam komunitas pembelajaran.

Rasionalitas peningkatan prososial mahasiswa melalui pembelajaran ecopedagogy berbasis learning community dirumuskan dalam dua aspek utama. Pertama, pembelajaran ecopedagogy merupakan suatu praktik transformative yang bermuatan tentang isu-isu lingkungan; analisis krisis lingkungan, penyebab kerusakan lingkungan; analisis potensi yang dapat diupayakan untuk menyelamatkan lingkungan. Namun demikian, pembelajaran ecopedagogy bukanlah suatu pendekatan pembelajaran yang berdiri atas disiplin ilmu IPA semata, tetapi juga social budaya di mana dampaknya dapat di rasakan oleh masyarakat secara luas.

Alasan kedua yang mendasari ialah tiga komponen modal profesional yang seharusnya dimiliki oleh calon guru, antara lain: (1) modal manusia secara luas mengacu pada bakat guru sebagai individu; (2) Modal sosial ialah kekuatan kolaboratif guru sebagai kelompok; dan (3) modal putusan adalah keahlian untuk membuat penilaian yang baik dalam profesi (Hargreaves \& Fullan, 2012). Kelebihan nilai komunitas ini ialah terletak pada kemampuan untuk memanfaatkan sumber daya yang dimiliki oleh anggota lain dalam pendidikan dan potensinya untuk menjembatani kesenjangan di mana pengetahuan dan atau keterampilan kurang (Muijs, West, \& Aincow, 2010; Pedder \& Opfer, 2011).

Berdasarkan paparan di atas, maka penelitian ini bertujuan untuk meningkatkan perilaku prososial mahasiswa STKIP Majenang melalui penerapan pembelajaran ecopedagogy berbasis learning community.

\section{METODE}

Penelitian ini menggunakan pendekatan penelitian tindakan dengan jenis penelitian tindakan kelas (PTK). Rancangan yang digunakan pada penelitian ini adalah rancangan penelitian tindakan kelas model Kemiis, McTaggart, \& Nixon (2014) yang terdiri perencanaan, pelaksanaan-observasi dan refleksi. 
Subyek dalam penelitian ini adalah mahasiswa program studi Pendidikan Guru Sekolah Dasar (PGSD) tahun angkatan 2019. Jumlah subyek pada penelitian ini adalah 20 orang mahasiswa calon guru SD.

Data yang dikumpulkan dalam penelitian ini meliputi dua aspek, yaitu (1) keterlaksanaan pembelajaran ecopedagogy berbasis learning community dan (2) perilaku prososial mahasiswa. Teknik pengumpulan data dalam penelitian ini menggunakan lembar angket, observasi, dan wawancara. Lembar angket digunakan untuk mengetahui perilaku prososial mahasiswa yang terdiri dari 20 item pernyataan. Sedangkan lembar observasi dan pedoman wawancara digunakan untuk memperoleh hasil keterlaksanaan pembelajaran ecopedagogy berbasis learning community dan perilaku prososial mahasiswa.

Data yang telah terkumpul dianalisis menggunakan teknik analisis deskriptif kualitatif yang mengacu pada skema Creswell (2015). Selanjutnya, dilakukan evaluasi keberhasilan tindakan berdasarkan kriteria yang telah ditetapkan sebesar $\geq 75 \%$ di tiap aspek.

\section{PEMBAHASAN}

Untuk mengetahui peningkatan perilaku prososial mahasiswa melalui pembelajaran ecopedagogy berbasis learning community, peneliti melakukan komparasi data yang dihasilkan dari tiga tahapan. Ketiga tahapan tersebut mencakup (1) data hasil identifikasi masalah, (2) data hasil tindakan siklus I, dan (3) data hasil tindakan siklus II. Masingmasing tahapan tersebut terurai sebagai berikut.

\section{Paparan Data Hasil Identifikasi Masalah}

Sebelum

melaksanakan

tindakan dalam penelitian ini, peneliti melakukan wawancara dan kuisioner pendahuluan kepada mahasiswa STKIP Majenang. Berdasarkan hasil wawancara dan kuisioner tersebut, dapat ditarik kesimpulan bahwa perilaku prososial mahasiswa berada di tingkatan normative, yakni sebesar $54 \%$.
Mengacu pada hasil tersebut, diketahui bahwa penerapan strategi pembelajaran ecopedagogy berbasis learning community belum pernah diterapkan kepada mahasiswa STKIP Majenang. Selanjutnya, pada aspek perilaku prososial diperoleh hasil bahwa hampir seluruh mahasiswa bersedia dan pernah memberikan bantuan ketika diminta baik secara verbal maupun non verbal (patuh). Hal ini sangat kontras jika dibandingkan dengan kesediaan pemberian bantuan secara sukarela (altruistik) maupun emosional.

Fakta ini kemudian didukung dengan hasil wawancara kepada 6 responden terpilih yang menghasilkan beberapa poin inti, antara lain: (a) aktivitas berbagi didominasi oleh mahasiswa dengan tingkat akademis sedang, misalnya kesediaan menempatkan pengetahuan dan kemampuan kepada teman yang notabene tidak memiliki kedekatan interpersonal; (b) 
aktivitas membantu sebagian besar dilakukan secara spontan dan sukarela kepada teman yang dirasakan memiliki kedekatan secara emosional. Sementara bantuan dipengaruhi pula oleh pertimbangan gender. Adapun bantuan diberikan kepada teman atas dorongan pengakuan diri (publik); dan (c) mahasiswa mampu merasakan apa yang dirasakan teman, namun kesulitan untuk menempatkan diri pada posisi teman yang merasa tidak nyaman. Adapun hasil kuisioner pra tindakan yang disajikan dalam tabel 1.

Tabel 1. Hasil Identifikasi Masalah Tentang Perilaku Prososial Mahasiswa

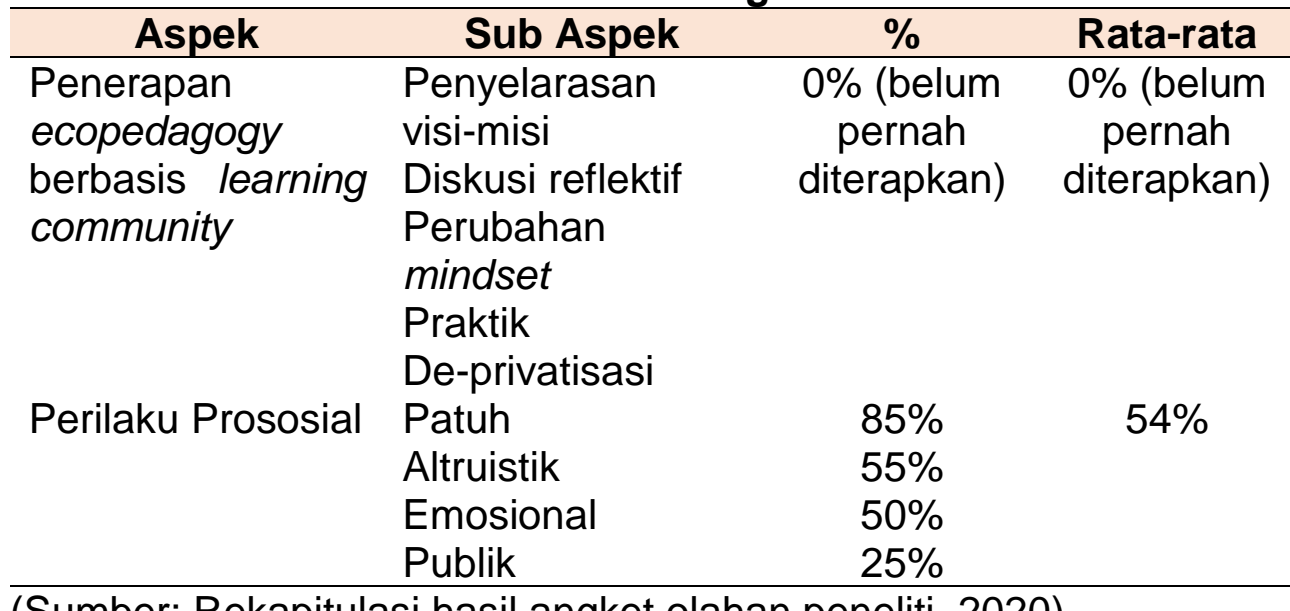

(Sumber: Rekapitulasi hasil angket olahan peneliti, 2020)

\section{Paparan Data Pelaksanaan} Tindakan Siklus I

\section{a. Perencanaan Tindakan}

Pelaksanaan tindakan siklus I dilakukan dalam dua pertemuan. Instrumen-instrumen penelitian juga dipersiapkan yang terdiri dari lembar observasi, pedoman wawancara, dan angket.

Lembar angket disusun untuk mengetahui perilaku prososial mahasiswa yang terdiri dari 20 item pernyataan. Lembar observasi juga dipersiapkan untuk mengukur dua aspek yang diteliti, yaitu keterlaksanaan pembelajaran dan perilaku prososial. Sedangkan lembar observasi dan pedoman wawancara terdiri dari keterlaksanaan pembelajaran ecopedagogy berbasis learning community dan perilaku prososial mahasiswa yang dilakukan selama kegiatan pelaksanaan tindakan berlangsung. Pemilihan 6 informan penelitian didasari oleh pertimbangan kemampuan akademis mahasiswa dan jenis kelamin yang dibagi menjadi 3 golongan, yaitu mahasiswa berkemampuan tinggi, mahasiswa berkemampuan sedang, dan mahasiswa berkemampuan akademis kurang.

b. Pelaksanaan dan Pengamatan Tahap pelaksanaan tindakan pada siklus ini terdiri atas 2 pertemuan. Pertemuan 1 dan 2 dipergunakan untuk kegiatan penerapan pembelajaran ecopedagogy berbasis learning community. Pada akhir pertemuan 2 diisi dengan kegiatan wawancara.

Berdasarkan observasi yang dilakukan kepada seluruh mahasiswa PGSD tahun angkatan 2019 yang berjumlah 20 orang dan wawancara kepada 6 subyek 
terpilih pada akhir pertemuan siklus I dapat diperoleh hasil pada tabel 2 sebagai berikut.

Tabel 2. Data Hasil Keterlaksanaan Pembelajaran Ecopedagogy berbasis Learning Community Siklus I

\begin{tabular}{lcccc}
\hline \multicolumn{1}{c}{ Aspek } & $\begin{array}{c}\text { No. } \\
\text { Sub } \\
\text { Aspek }\end{array}$ & $\begin{array}{c}\text { Sebelum } \\
\text { Tindakan }\end{array}$ & $\begin{array}{c}\text { Setelah Tindakan } \\
\text { O }\end{array}$ & W \\
\hline Keterlaksanaan & 1 & 0\% (belum & $70 \%$ & $83 \%$ \\
Pembelajaran & 2 & pernah & $50 \%$ & $33 \%$ \\
Ecopedagogy & 3 & diterapkan) & $60 \%$ & $67 \%$ \\
Berbasis Learning & 4 & & $40 \%$ & $33 \%$ \\
Community & 5 & & $35 \%$ & $33 \%$ \\
Rata-rata & & $0 \%$ & $51 \%$ & $50 \%$ \\
Rata-rata keberhasilan tindakan & & $51 \%$ & \\
\hline
\end{tabular}

(Sumber: Rekapitulasi Observasi dan Wawancara Keterlaksanaan Ecopedagogy Berbasis Learning Community Siklus I, 2020).

Tabel 3. Data Hasil Perilaku Prososial Mahasiswa Siklus I

\begin{tabular}{lccccc}
\hline \multicolumn{1}{c}{ Aspek } & $\begin{array}{c}\text { No. } \\
\text { Sub } \\
\text { Aspek }\end{array}$ & $\begin{array}{c}\text { Sebelum } \\
\text { Tindakan }\end{array}$ & O Setelah Tindakan \\
& 1 & $85 \%$ & $85 \%$ & $95 \%$ & A \\
\hline Perilaku Prososial & 2 & $55 \%$ & $60 \%$ & $65 \%$ & $67 \%$ \\
& 3 & $50 \%$ & $40 \%$ & $55 \%$ & $50 \%$ \\
& 4 & $25 \%$ & $20 \%$ & $65 \%$ & $50 \%$ \\
$\begin{array}{l}\text { Rata-rata } \\
\text { Rata-rata keberhasilan }\end{array}$ & & $54 \%$ & $51 \%$ & $70 \%$ & $63 \%$ \\
tindakan & \multicolumn{5}{c}{$61 \%$} \\
\hline
\end{tabular}

(Sumber: Rekapitulasi Observasi, Angket, dan Wawancara Perilaku Prososial Siklus I, 2020).

\section{c. Refleksi}

Refleksi dilakukan oleh peneliti dan dua rekan observer untuk mengetahui tingkat keberhasilan per siklus dan keberlanjutan pelaksanaan tindakan. Berdasarkan tabel 2 tentang data hasil keterlaksanaan pembelajaran ecopedagogy berbasis learning community mengalami peningkatan yang signifikan dari pratindakan sebesar $0 \%$ atau tidak pernah diterapkan menjadi $51 \%$. Namun demikian, hasil observasi secara keseluruhan kepada 20 mahasiswa tidak berlangsung secara maksimal.
Sebagai contoh, pada sub aspek 1 tentang sebagian besar mahasiswa telah memahami konteks isu yang dikaji. Tetapi, pemahaman tersebut tidak ditindaklanjuti pada sintak berikutnya, yaitu diskusi reflektif hingga praktik.

Dalam 2 pertemuan yang dilakukan di siklus I, secara konsisten hanya beberapa mahasiswa yang dapat menjalankan sintak pembelajaran secara keseluruhan. Hal inilah yang menyebabkan hasil pada sub aspek 5 hanya sebesar $35 \%$.

Di sisi lain, hasil wawancara juga didapatkan ketuntasan tentang 
alur pembelajaran hanya 50\%. Dalam sebuah wawancara kepada 3 informan, dapat disimpulkan bahwa kesulitan mereka melaksanakan alur pembelajaran dengan baik ialah pada kejelasan dan kemenarikan pembelajaran yang dikemas. Hal ini menunjukkan bahwa hanya sebagian mahasiswa yang dapat memahami substansi dari pembelajaran yang dilaksanakan. Dengan demikian dapat disimpulkan bahwa ketidaktuntasan seluruh mahasiswa dalam melaksanakan alur ternyata juga dipengaruhi oleh desain pembelajaran yang kurang menarik.

Berdasarkan tabel 3 dapat diketahui bahwa rata-rata keberhasilan pada aspek perilaku prososial mahasiswa mengalami peningkatan dari hasil angket pada tahap identifikasi masalah yaitu $54 \%$ menjadi $61 \%$ di siklus I. Hasil angket sub aspek 1 yakni patuh meningkat secara signifikan yang semula hanya sebesar $85 \%$ menjadi $95 \%$ saat siklus I. Meski demikian, apabila disandingkan dengan hasil observasi di siklus I, kepatuhan terhadap pemberian bantuan didominasi dari permintaan secara verbal. Sebagian besar mahasiswa jarang memberikan respon jawaban bahwa mereka tidak dapat mengenali permintaan bantuan secara non verbal, misalnya gestur tubuh atau ekspresi.

Hasil angket pada sub aspek 2 yaitu altruistik dan sub aspek 3 yaitu emosional tidak jauh berbeda dengan hasil identifikasi masalah. Secara konsisten hanya sebagian mahasiswa dari 20 responden yang memberikan respon jawaban bahwa bantuan diberikan secara suka rela atau atas dasar motif simpati. Hasil pada sub aspek 2 dan 3 ini sejalan jika disandingkan dengan hasil pada sub aspek 1 , yang artinya bahwa mahasiswa memang lebih banyak memberikan bantuan ketika teman memang memintanya.

Hal yang kontras justru ditunjukkan pada sub aspek 4 yaitu publik, di mana saat tahap identifikasi masalah hanya 25\% responden yang memberikan respon jawaban pemberian bantuan baik secara terbuka maupun tersembunyi. Sedangkan, pada saat siklus I menjadi sebanyak $65 \%$ responden. Perbedaan hasil yang signifikan ini disebabkan oleh kegiatan pembelajaran melalui ecopedagogy berbasis learning community memang belum diterapkan. Sementara pembelajaran ini sendiri menagih kegiatan diskusi tiap anggota kelompok. Perbedaan ini dipertegas dengan hasil observasi, sebanyak $20 \%$ mahasiswa menunjukkan pemberian bantuan publik.

Adanya inkonsistensi data yang muncul pada sub aspek 4 kemudian diperjelas melalui hasil wawancara yang menunjukkan bahwa bantuan publik mahasiswa sebesar $50 \%$. Pada sub aspek ini, bantuan publik dipetakan menjadi dua kategori, pertama ialah bantuan yang sengaja diberikan untuk mendapatkan pujian atau menampilkan bantuan kepada observer. Kategori kedua ialah pemberian bantuan yang disembunyikan atau sengaja tidak ditunjukkan. Berdasarkan hasil wawancara tersebut terungkap bahwa bantuan yang diberikan memang sengaja tidak ditampilkan. 
Hal inilah yang menyebabkan saat pengamatan dilakukan, observer hanya menemukan sebesar $20 \%$ tindakan bantuan publik.

Apabila dilakukan analisis antara hasil siklus I dengan kriteria tindakan sebesar $\geq 75 \%$, maka penelitian tindakan pada siklus ini dinyatakan belum berhasil. Oleh karena itu, peneliti dan observer menyepakati adanya kelanjutan tindakan ke siklus II.

\section{Paparan Data Pelaksanaan Tindakan SIklus II}

\section{a. Perencanaan Tindakan}

Berdasarkan hasil refleksi siklus I yang dilakukan oleh peneliti dan observer, pada siklus II ini peneliti mengubah susunan kelompok mahasiswa yang didasarkan pada kemampuan akademis yang berbeda yaitu, mahasiswa dengan kemampuan akademis rendah, sedang, dan tinggi.

Disamping itu, peneliti melakukan modifikasi pembelajaran dengan menggunakan pembelajaran berbasis tempat. Artinya, mahasiswa diintegrasikan pada aktifitas riil pengamatan terhadap alam lingkungan sekitar kampus. Hal yang mendasari pemilihan pembelajaran alam ialah sebagai efek peremajaan perhatian. Efek peremajaan perhatian melalui pembelajaran berbasis alam pada orang dewasa telah banyak dibuktikan oleh peneltian sebelumnya, misalnya kelelahan secara mental dan meningkatkan konsentrasi (Kuo, et al., 2019; Li \& Sullivan, 2016). Pertimbangan lainnya yaitu pembelajaran melalui alam dapat mendorong hubungan manusia dengan alam, mencegah stres, serta memiliki efek tambahan positif bagi kesehatan (Frumkin, et al., 2017; Kuo, 2015).

b. Pelaksanaan Tindakan dan Pengamatan

Tahap pelaksanaan tindakan pada siklus ini terdiri atas 2 pertemuan. Pertemuan 1 dan 2 dipergunakan untuk kegiatan penerapan pembelajaran ecopedagogy berbasis learning community. Pada akhir pertemuan 2 diisi dengan kegiatan wawancara.

Sebagaimana refleksi pada siklus I, pembelajaran di pusatkan pada pemanfaatan lingkungan kampus. Adapaun pengintegrasian lingkungan dalam pembelajaran ecopedagogy berbasis learning community tersaji dalam tabel 4 .

Berdasarkan observasi yang dilakukan kepada seluruh mahasiswa PGSD yang berjumlah 20 orang dan wawancara kepada 6 subyek terpilih pada akhir pertemuan siklus I dapat diperoleh hasil pada tabel 5 .

Tabel 4. Alur Pembelajaran Pembelajaran Ecopedagogy Berbasis Learning Community Siklus II

\begin{tabular}{|c|c|c|}
\hline Langkah & Sub Aspek & Kegiatan \\
\hline 1 & Visi/misi & $\begin{array}{l}\text { Mahasiswa menyimak contoh kasus isu } \\
\text { lingkungan yang disaijkan oleh dosen }\end{array}$ \\
\hline 2 & Diskusi reflektif & $\begin{array}{l}\text { Kelompok menentukan isu lingkungan } \\
\text { yang akan dikaji }\end{array}$ \\
\hline 3 & $\begin{array}{l}\text { Perubahan } \\
\text { mindset }\end{array}$ & $\begin{array}{l}\text { Mahasiswa dalam kelompok } \\
\text { mengidentifikasi masalah lingkungan } \\
\text { yang terjadi di sekitar kampus, penyebab, }\end{array}$ \\
\hline
\end{tabular}




\begin{tabular}{|c|c|c|}
\hline & & $\begin{array}{l}\text { solusi, dan ide pengembangan } \\
\text { lingkungan }\end{array}$ \\
\hline 4 & Praktik & $\begin{array}{l}\text { Kelompok menyajikan hasil identifikasi ke } \\
\text { dalam media peta isu lingkungan }\end{array}$ \\
\hline 5 & De-privatisasi & $\begin{array}{l}\text { Masing-masing kelompok } \\
\text { mempertukarkan dan } \\
\text { mengkomunikasikan peta isu } \\
\text { lingkungannya. }\end{array}$ \\
\hline
\end{tabular}

Tabel 5. Data Hasil Keterlaksanaan Pembelajaran Ecopedagogy Berbasis Learning Community Siklus 2

\begin{tabular}{lccc}
\hline \multicolumn{1}{c}{ Aspek } & $\begin{array}{c}\text { No. Sub } \\
\text { Aspek }\end{array}$ & \multicolumn{2}{c}{$\begin{array}{c}\text { Setelah } \\
\text { Tindakan }\end{array}$} \\
& & O & W \\
\hline Keterlaksanaan & 1 & $90 \%$ & $100 \%$ \\
Pembelajaran Ecopedagogy & 2 & $75 \%$ & $83 \%$ \\
Berbasis Community Learning & 3 & $80 \%$ & $83 \%$ \\
& 4 & $75 \%$ & $67 \%$ \\
Rata-rata & 5 & $70 \%$ & $67 \%$ \\
Rata-rata keberhasilan tindakan & \multicolumn{4}{c}{$78 \%$} & $80 \%$ \\
\hline
\end{tabular}

(Sumber: Rekapitulasi Observasi dan Wawancara Keterlaksanaan Ecopedagogy Berbasis Learning Community Siklus 2, 2020).

Tabel 6. Data Hasil Perilaku Prososial Mahasiswa Siklus 2

\begin{tabular}{lcccc}
\hline \multicolumn{1}{c}{ Aspek } & No. Sub & \multicolumn{3}{c}{ Setelah Tindakan } \\
& Aspek & 0 & W & A \\
\hline Perilaku Prososial & 1 & $85 \%$ & $100 \%$ & $100 \%$ \\
& 2 & $75 \%$ & $83 \%$ & $90 \%$ \\
& 3 & $70 \%$ & $83 \%$ & $85 \%$ \\
Rata-rata & 4 & $40 \%$ & $33 \%$ & $60 \%$ \\
Rata-rata keberhasilan tindakan & & & $75 \%$ & $84 \%$ \\
\hline
\end{tabular}

(Sumber: Rekapitulasi Observasi, Angket, dan Wawancara Perilaku Prososial Siklus II, 2020).

\section{c. Refleksi}

Berdasarkan tabel 5 dapat diketahui bahwa rata-rata keberhasilan aspek keterlaksanaan ecopedagogy berbasis learning community diperoleh hasil sebesar $79 \%$. Hasil observasi secara keseluruhan kepada 20 mahasiswa mencakup lima sub aspek berlangsung baik, yakni sebesar $78 \%$. Hasil wawancara juga didapatkan ketuntasan tentang alur pembelajaran sebesar $80 \%$. Hal ini menunjukkan bahwa sebagian besar mahasiswa yang dapat memahami substansi atau konteks pembelajaran.

Berdasarkan tabel 6 dapat diketahui bahwa rata-rata keberhasilan pada aspek perilaku prososial mahasiswa sebesar $76 \%$. Hasil angket dan wawancara pada 
sub aspek 1 yakni patuh menunjukkan bahwa seluruh mahasiswa dapat memberikan bantuan kepada teman baik secara verbal maupun non verbal. Hasil ini sejalan jika disandingkan dengan hasil observasi. Sebanyak 85\% mahasiswa menunjukkan sikap tanggap ketika dimintai bantuan ketika pelaksanaan pembelajaran berlangsung, khususnya pada saat kegiatan praktik.

Sementara, hasil angket pada sub aspek 2 dan 3 , lebih dari $80 \%$ mahasiswa menyatakan telah melakukan pemberian bantuan secara suka rela dan atau atas dasar motif simpati. Meskipun hasil observasi menunjukkan hanya $70 \%$ mahasiswa yang menunjukkan pola bantuan seperti ini, tetapi keterbatasan pengamatan kemudian diperkuat dengan hasil wawancara yang menyatakan bahwa mahasiswa memberikan bantuan tidak secara langsung, misalnya dengan motivasi atau diam-diam. Hal ini sejalan dengan hasil observasi pada sub aspek 4, diketahui sebanyak $40 \%$ mahasiswa saja yang menunjukkan bantuan di depan publik. Artinya, sebanyak $60 \%$ mahasiswa sebenarnya sering memberikan bantuan dan dukungan tanpa atribut lain (tidak ditunjukkan).

Konklusi dari hasil analisis yang telah dijabarkan di atas menunjukkan bahwa tindakan pada siklus II sudah mencapai kriteria yang ditetapkan dalam penelitian ini sebesar $\geq 75 \%$.

Hasil penelitian secara keseluruhan telah menunjukkan bahwa komunitas pembelajaran dapat diimplementasikan sebagai bagian dari ekopedagogi dalam meningkatkan perilaku prososial mahasiswa. Dalam studi ini, fenomena penting dan saling terkait disajikan dalam dua aspek.

Pertama, keberhasilan pembelajaran yang melibatkan lingkungan di sekitar mahasiswa. Berkaitan dengan hal ini, lingkungan sekitar sebagai salah satu bentuk pendidikan pengalaman yang termasuk ke dalam pedagogi berbasis tempat (Zocher \& Hougham, 2020). Ecopedagogy dalam penelitian ini telah terbukti memungkinkan mahasiswa untuk memiliki keterhubungan antara konten sains, pengalaman dalam kehidupan sehari-hari, keterampilan observasi, dan meningkatkan kapasitas untuk peduli terhadap lingkungan di sekitar mereka. Hal ini sejalan dengan beberapa studi yang menunjukkan bahwa melibatkan pemuda dalam pendidikan berbasis tempat dapat menumbuhkan keinginan untuk menjadi pengamat alam yang lebih baik (Novitasari \& Muhammad, 2020; Hougham et al., 2018; Land \& Zimmerman, 2015).

Sementara dalam praktiknya, pembelajaran ecopedagogy diintegrasikan dalam komunitas. Kemampuan komunitas dalam memahami konteks lingkungan hingga merumuskan potensi pengembangan lingkungan menunjukkan bahwa setiap mahasiswa telah membentuk hubungan dengan alam. Koneksi alam mengacu pada perasaan subjektif individu dari hubungan mereka dengan alam dan mencakup aspek afektif, kognitif, dan pengalaman dari hubungan itu (Cleary, et al., 2020; Cleary, et al., 2017; Restall \& Conrad, 2015). 
Kedua, adanya peningkatan perilaku prososial mahasiswa yang dihasilkan dari penerapan ecopedagogy berbasis learning community. Sejalan dengan uraian sebelumnya tentang pendidikan berbasis tempat, beberapa bukti menunjukkan bahwa keterhubungan manusia dengan tempat dapat berkontribusi pada keterlibatan dalam perilaku prososial dan pro-lingkungan (Ramkissoon, 2020; Rosa et al., 2018; Novitasari, 2017; De Dreu et al., 2015). Berdasarkan data yang diperoleh, ketika mahasiswa dimasukkan ke dalam kelompok yang heterogen terjadi fungsionalitas dan inovasi yang kuat bagi masing-masing anggotanya. Hal inilah yang mendorong setiap mahasiswa mengembangkan perilaku-perilaku prososialnya. Setiap individu membangun psikologi kelompok yang mencakup kecenderungan untuk (a) mengidentifikasi karakteristik anggotanya, berempati dengan kebutuhan dan minat sesama anggota kelompok, (c) pengorbanan diri, kepercayaan, dan bekerja sama dengan anggota kelompok lainnya, dan (d) berkomitmen serta berkontribusi pada berfungsinya kelompok.

Temuan dari penelitian ini juga memberikan wawasan tentang pengalaman yang muncul selama penerapan pembelajaran terjadi. Misalnya, salah satu tema paling konsisten adalah berperilaku prososial membantu mahasiswa untuk menyadari bahwa tindakan tersebut memiliki dampak yang jauh lebih besar. Dikombinasikan dengan studi sebelumnya yang memiliki temuan serupa (Mayr \& Freund., 2020; Padilla-Walker et al., 2015; Caprara \& Steca, 2005), penelitian ini menunjukkan bahwa langkah penting untuk mendorong perilaku prososial adalah membantu orang memahami input dan output yang dihasilkan dalam berperilaku prososial.

\section{SIMPULAN}

Berdasarkan hasil penelitian yang telah dilakukan, maka dapat disimpulkan bahwa penerapan pembelajaran ecopedagogy berbasis learning community dapat meningkatkan perilaku prososial mahasiswa. Peningkatan tersebut terjadi dalam dua aspek, antara lain: keterlaksanaan pembelajaran ecopedagogy berbasis learning community pada siklus I sebesar $51 \%$ dan siklus 2 sebesar $79 \%$. Sementara perilaku prososial mahasiswa pada siklus 1 sebesar $61 \%$ meningkat menjadi sebesar $76 \%$ di siklus II.

Akan tetapi, penelitian ini masih memiliki keterbatasan waktu penelitian dan hanya terfokus pada aspek perilaku prososial. Oleh karena itu, diharapkan penelitian di masa mendatang dapat menganalisa dan menyelidiki secara lebih rinci tentang efek lain yang dihasilkan dari implementasi pembelajaran ini, misalnya kecerdasan ekologis calon guru SD. 


\section{DAFTAR PUSTAKA}

Alden, L., \& Trew, J. (2013). If it makes you happy: Engaging in kind acts increases positive affect in socially anxious individual. Emotion, 13(1), 64.

Apple, M., \& Au, W. (2009). Politics, Theory, and Reality in Critical Pedagogy. In R. Cowen, \& M. Kazamias, The Routledge International Handbook of Critical Education (pp. 3-20). New York: Routledge.

Caprara, G. V., \& Steca, P. (2005). Self-efficacy beliefs as determinants of prosocial behavior conducive to life satisfaction across ages. Journal of Social and Clinical Psychology, 24(2), 191-217. doi:10.1521/jscp.24.2.191.6227 1.

Cleary, A., Fielding, K. S., Bell, S. L., Murray, Z., \& Roiko, A. (2017). Exploring potential mechanisms involved in the relationship between eudaimonic well being and nature connection. Landscape and Urban Planning, 158, 119-128. doi:10.1016/j.landurbplan.2016. 10.003

Cleary, A., Fielding, K., Murray, Z., \& Roiko, A. (2020). Predictors of nature connection among urban residents: Assessing the role of childhood and adult nature experiences.

Environment and Behavior, 52(6), 579-610. doi.org/10.1177/001391651881 1431.

Creswell, J. (2015). Riset pendidikan: perencanaan, pelaksanaan, dan evaluasi riset kualitatif dan kuantitatif (Terjemahan dari
Helly Prajitno Soetjipto). Yogyakarta: Pustaka Pelajar.

De Dreu, C. K., Dussel, D. B., \& Velden, F. S. (2015). In intergroup conflict, self-sacrifice is stronger among pro-social individuals, and parochial altruism emerges especially among cognitively taxed individuals. Frontiers in Psychology, 6, 572. doi.org/10.3389/fpsyg.2015.005 72.

Frumkin, H., Bratman, G. N., Breslow, S. J., Cochran, B., Kahn, P. H., \& al., e. (2017). Nature contact and human health: A research agenda. Environmental Health Perspectives, 125(7), 075001. doi.org/10.1289/EHP1663.

Geiser, C., Okun, \& Grano, C. (2014). Who is motivated to volunteer? A latnt profile analysis linking volunteer motivation to frequency of volunteering. Psychological Test and Assessment Modeling, 56, 324.

Hargreaves, A., \& Fullan, M. (2012). Professional Capital: Transforming Teaching in Every School. New York: Teachers College Press.

Hougham, R. J., Nutter, M., \& Graham, C. (2018). Bridging natural and digital domains: Attitudes, confidence, and interest in using technology to learn outdoors. Journal of Experiential Education, 41(2), 154-169. doi.org/10.1177/105382591775 1203

Kemiis, S., McTaggart, R., \& Nixon, R. (2014). The Action Research Planner. New York: Springer. 
Kuo, M. (2015). How might contact with nature promote human health? Promising mechanisms and a possible central pathway. Frontiers in Psychology, 6 , 1093. doi: 10.3389/fpsyg.2015.01093.

Kuo, M., Barnes, M., \& Jordan, C. (2019). Do experiences with nature promote learning? Converging evidence of a cause-and-effect relationship. Frontiers in Psychology, 10, 305. doi: 10.3389/fpsyg.2019.00305.

Lampridis, E., \& Papastylianou, D. (2014). Procosial behavioural tendencies and orientation towards individualismcollectivism of Greek young adults. International Journal of Adolescence and Youth, 22(3), 268-282.

Land, S. M., \& Zimmerman, H. T. (2015). Socio-technical dimensions of an outdoor mobile learning environment: $A$ three-phase design-based research investigation. Education Technology Research Development, 63(2), 229-255.

doi.org/10.1007/s11423-0159369-6.

Li, D., \& Sullivan, W. C. (2016). Impact of views to school landscapes on recovery from stress and mental fatigue. Landscape and Urban Planning, 148, 149-158. doi.org/10.1016/j.landurbplan.2 015.12 .015 .

Mayr, U., \& Freund, A. M. (2020). Do We Become More Prosocial as we age, and if so, why? Current Directions in Psychological Science, 29(3), 248-254. doi.org/10.1177/096372142091 0811 .
Misiaszek, G. (2016). Ecopedagogy as an element of citizenship education: The dialectic of global/local spheres of citizenship and critical environmental pedagogies. Int Rev Educ, 62:587-607.

Muijs, West, M., \& Aincow, M. (2010). Why network? Theoretical perspectives on networking. School Effectiveness and School Improvement. An International Journal of Research, Policy and Practice, 5-26.

Novitasari, N. (2017). Urgensi peran sekolah sebagai komunitas adil untuk mentransformasikan perilaku prososial siswa SD di era digital native. Seminar Nasional PGSD Unikama (pp. 1, 133-143). Malang: PGSD Unikama.

Novitasari, N., \& Muhammad, A. (2020). Pengembangan bahan ajar fiksi membaca intensif cerita petualangan berbasis ekologi siswa sekolah dasar. Jurnal Bidang Pendidikan Dasar, 4(1), 47-57.

Padilla-Walker, L. M., Carlo, G., \& Nielson, M. G. ( 2015). Does helping keep teens protected? Longitudinal bidirectional relations between prosocial behavior and problem behavior. Child Development, 86(6), 20151759-1772. doi: 10.1111/cdev.12411.

Pedder, D., \& Opfer, D. (2011). Are we realising the full potential of teachers' professional learning in schools in England? Policy issues and recommendations from a national study. Professional Development in Education , 741-758. 
Ramkissoon, H. (2020). COVID-19

place confinement, pro-Social,

pro-environmental behaviors, and residents' wellbeing: A new conceptual framework.

Frontiers Psychology, 11, 2248. doi: 10.3389/fpsyg.2020.02248.

Restall, B., \& Conrad, E. (2015). A literature review of connectedness to nature and its potential for environmental management. Journal of Environmental Management, 159, 264-278.

doi:10.1016/j.jenvman.2015.05. 022.

Rosa, C. D., Profice, C. C., \& Collado, S. (2018). Nature experiences and adults' self-reported proenvironmental behaviors: The role of connectedness to nature and childhood nature experiences. Frontiers in Psychology, 9, 1055. doi: 10.3389/fpsyg.2018.01055.

Vecina, M., \& Chacon, F. (2013). Volunteering and well-being: Is pleasure-based rather than pressure-based prosocial motivation that which is related to positive effects? Journal of Applied Social Psychology, 43, 870-878.

Weinstein, N., \& Ryan, R. (2010). When helping helps:

Autonomous motivation for prosocial behavior and its influence on well-being for the helper and recipient. Journal of Personality and Social Psychology, 98(2), 222.

Zocher, J., \& Hougham, R. (2020). Implementing ecopedagogy as an experiential approach to decolonizing Science education. Journal of Experiential Education, 43(3), 232-247. 